\title{
The Political Uses of the Past During the Cold War: Conservative Intellectuals and the Military Dictatorship in Brazil
}

\author{
Diogo Cunha ${ }^{1}$ \\ https://orcid.org/0000-0002-3549-7059
}

${ }^{1}$ Universidade Federal de Pernambuco. Political Science. Recife/PE, Brazil

The aim of this paper is to examine how, in the context of the Cold War and Latin America's National Security dictatorships, conservative Brazilian intellectuals turned to history to demonstrate the country's 'incompatibility' with progressive values and left-wing government. It analyzes a selection of lectures given by acclaimed conservative intellectuals at the National War College during the 1960s and 70s. An examination of these lectures demonstrates that many of the elements chosen to define 'national identity' under the 'Estado Novo' dictatorship of 1937-45 - such as the valorization of miscegenation, a belief in the docile nature of the Brazilian people, the exaltation of work and the idea of a nation founded on cohesion and cooperation - were revived after 1964. Thus, conservative intellectuals made an important contribution to legitimizing the military dictatorship of 1964-85 by inscribing it within what they believed the Brazilian tradition to be, presenting it as the only regime capable of preserving national unity and culture against the threats posed by Marxism and communism.

Keywords: Brazilian military dictatorship; conservative intellectuals; political uses of the past; culture; national identity.

http://doi.org/10.1590/1981-3821202100030001

Correspondence: diogo.accunha@ufpe.br

This publication is registered under a CC-BY Licence.

Financial support: Coordenação de Aperfeiçoamento de Pessoal de Nível Superior (Capes). 
Introduction: conservative intellectuals and ideology in Brazil's Cold War: some comments on the literature and methods

his paper is part of broader research on the relationship between conservative intellectuals and the Brazilian military dictatorship ${ }^{1}$. It seeks to examine the extent to which this conservative intelligentsia was a source of legitimation for the regime. Specifically, it analyzes the ways in which some intellectuals turned to Brazilian history in the context of the Cold War and Latin America's National Security dictatorships to demonstrate Brazil's 'incompatibility' with progressive values and left-wing government. Below I shall analyze a sample of lectures given by acclaimed conservative intellectuals at the National War College (ESG) ${ }^{2}$ during the 1960s and 70s.

It is essential to initially explain the conceptual, institutional and sociological framework of this study. To this end, three questions must be answered: What do I mean by 'conservatism'? Why have I selected the lectures given at the ESG? How and why did I select the specific intellectuals and lectures analyzed in this paper?

The concept of conservatism has been widely discussed in human and social sciences $^{3}$. For this study, the analyses developed by Albert Hirschman were particularly useful. In his stimulating work, 'The Rhetoric of Reaction' (1991), Hirschman set out to reveal the argumentative structure of the political discourse of the forces of reaction against various progressive reform movements, from the French Revolution to the present day. He identified three key arguments in conservative discourse over two centuries: the argument of perversity (that any initiative aimed at improving the social, political or economic order gives rise to results that are contrary to the objectives pursued); the argument of futility (that projects seeking to transform the social order do not change the current status quo in any way at all, i.e., they have no effect); and the argument of jeopardy (that reform programs tend to undermine previously acquired advantages and rights).

\footnotetext{
${ }^{1}$ The author wishes to thank the invaluable comments made by the reviewers, whose suggestions sharpened both my prose and my argument.

${ }^{2}$ We have used the Portuguese acronym of the institution's name: ESG (Escola Superior de Guerra). ${ }^{3}$ Cf., amongst others: Mannheim (2009), Rémond (1982), Oakeshott (1962), Huntington (1957), Nisbet (1987), Scruton $(2017,2015)$, Bobbio (1995), and Coutinho (2014).
} 
These arguments are found to a greater or lesser extent in the lectures of the conservative intellectuals analyzed in this paper. Therefore, we consider conservatism to be a reactive behavior vis-à-vis progressive reform projects or more radical projects that seek to transform the social order motivated by one or more of the three arguments identified by Hirschman (1991).

With regard to the second question - why have I selected the lectures given at the ESG? - two reasons guided my choice. The first was the role of the ESG in drawing up and disseminating the National Security Doctrine (DSN) ${ }^{4}$. The ESG was a locus of interaction between civilians and the military as well as a training center for an elite destined to occupy positions at the highest levels of the State (STEPAN, 1975, p. 136). The second reason concerns the content of the lectures. The conservative intellectuals invited to give lectures at the ESG not only spoke about the DSN but also, in addition to the strictly political issues, addressed very broad themes, such as the formation of the Brazilian people and their psychology, culture, national identity, and the elements that constituted the Nation. These were subjects that extended well beyond the more well-known aspects of the DSN.

Until recently, studies of right-wing ideologies and political ideas in Brazil during the 1960s and 70s had been limited to the DSN, which for a long time was conceived as a general theory for exercising power in the context of the Cold War. It should be emphasized that studies on ideologies and, more generally, political ideas during this period have evolved very little since the 1970s. They have remained focused on the main topics of the DSN and the extent to which Latin American militaries used it to govern their countries. According to an initial study published by Joseph Comblin (1978), the DSN was imported from the United States to be used by the Latin American armed forces in the fight against communism. More recently, the importance of the DSN has been viewed with greater nuance and reassessed. João Roberto Martins Filho (2004) highlighted problems with Comblin's work (1978) and considered his description of the historical process of building the dictatorial mentality somewhat simplistic. According to Comblin's conclusions (1978), as noted by Martins Filho (2004), Latin American military leaders had no idea of the type of society they were going to found, or even that they were going to create new regimes. From this perspective,

${ }^{4}$ As in the previous case, we have used the Portuguese acronym of the term 'Doutrina de Segurança Nacional' (DSN). 
the Latin American military is a mere 'ideological puppet' without the ability to create its own myths, doctrines or ideologies. Maud Chirio (2012, p. 27) reminds us that the influences on military thinking developed during the 1950s and 60s were diverse and possessed strong national specificities. The Brazilian specificities have been analyzed by Luís Felipe Miguel (2002), who described how the ESG gave the DSN its own characteristics by using elements of Brazilian tradition and political thought. I have been persuaded that studying the lectures given by conservative intellectuals at the ESG will enable me to broaden the understanding of the ideologies and political ideas of the military dictatorship.

We turn now to the third question, regarding the selection of the intellectuals and lectures that I have analyzed. As mentioned earlier, this paper is part of broader research on the relationship between the conservative intellectuals more specifically those who were part of the Brazilian Academy of Letters (ABL) and the military dictatorship. The study of the ABL led me towards detailed research on those who occupied the chairs at the ABL during this period. A prosopographical analysis of all the members of the institution between 1961 and 1979 enabled me to sketch out an accurate profile and identify a sector of the Brazilian intelligentsia that has remained neglected by researchers, and thereby forgotten, largely because of the ascendency of the 'cultural hegemony' of the left (SCHWARZ, 1978). This topic will not be delved into within the limits of this paper, since it has been the subject of previous publications (CUNHA, 2015). Thus, it is my previous work on the role of conservative intellectuals during the 1960s and 70s that justifies the choice of those being analyzed in this paper. The names of the intellectuals selected for this study are representative of the 'petit monde'5 of conservative Brazilian intellectuals to which I have had access through institutions such as the ABL, the Brazilian Historical and Geographic Institute (IHGB) and the Federal Council of Culture (CFC).

Clarification is needed. I am not suggesting that there was a mechanical and simplistic relationship between conservative intellectuals and the Brazilian military regime. As Angela de Castro Gomes has stated (2007, p. 47), the relationship

5The expression "little world' was used by Jean-Paul Sartre (1964) in a text written after the death of Albert Camus to refer to intellectual coteries.

$$
\text { (2021) } 15(3) \quad \text { e0001-4/32 }
$$


between intellectuals and political power is relatively complex. A wide range of approaches, negotiations and interests may be established between them. In other words, I do not consider that, in the aftermath of the 1964 coup, the military was able to 'coopt' the intelligentsia nor that the latter in turn created ex nihilo a coherent, complete discourse on national identity and Brazilian history for the sole purpose of legitimizing the military dictatorship. These conservative intellectuals had gained respectability and had long careers independent of the military dictatorship. Moreover, they had addressed and reformulated issues considered crucial to Brazilian political thought ever since the 1920s. What occurred in the 1960s and 70s was rather a case of 'pre-established harmony' - to take up Leibniz's expression used by Gisèle Sapiro (1999) in her work on French intellectuals during the German occupation during World War II - between the worldview of conservative intellectuals and that of the military who took power in 1964. This convergence is attested by studies on the political propaganda of the military dictatorship or on public policies in the area of culture. In the first case, Carlos Fico's (1997) works have demonstrated how political propaganda was grounded in a reading of Brazil, particularly as developed by Gilberto Freyre (FICO, 2003, p. 196, 1997). In the second case, Tatyana Maia (2010) analyzed the experience of the Federal Council of Culture, giving priority to the role of civism and patriotism in drawing up cultural policies between 1967 and 1975.

The hypothesis herein is that conservative intellectuals played an important role in the mechanisms of the post-1964 State legitimation. As Max Weber has already stated (2015), the notion of legitimacy is the key to the problem of political power. According to Maurice Duverger (1962, p. 15), most men believe that power must have a certain nature, based on certain principles, adopt a certain form, and be founded on a certain origin. In this sense, the role of beliefs and values, often originating from a historical construction, are essential in legitimizing political regimes, whether authoritarian or democratic. On the other hand, there is more than one form that legitimation can take. I suggest that the role of conservative intellectuals in producing a conservative discourse based on a certain reading of history and a certain conception of Brazilian culture was one of the instances of legitimization of the Brazilian military regime. With different forms of intervention in the public debate, these intellectuals emphasized the absence of 
conflict in Brazilian history and addressed such topics as the harmonious formation of the Brazilian people and their cordial and peaceful nature. They also supported the idea of a 'true Brazilian culture' that played a significant role in harmonizing differences and social conflicts, thereby showing a clear connection between their theses and the official discourse of the regime. This thus played a crucial role in building a specific reading of Brazil as a source of legitimacy for the dictatorship.

It must be said that the topic of political thought/conservative intellectuals has been studied predominantly by Brazilian human and social scientists. In political science, the development of these studies was pioneered by Wanderley Guilherme dos Santos in the 1960s and 70s (1978; 1970; 1967), followed by Bolívar Lamounier (1978), Luiz Werneck Vianna (2004), Gildo Marçal Brandão (2007) and more recently by a new generation of political scientists ${ }^{6}$. Among the sociologists, Sérgio Miceli took a Bourdieusian approach in 'Intelectuais e classes dirigentes no Brasil' (1979), whose importance in opening new research paths on intellectuals cannot be overlooked. Finally, such historians as dealt with the theme in the 1980s and 90s drew on the French 'history of intellectuals' tradition. This was the case of Angela de Castro Gomes with her works on intellectual sociability in the First Republic (1999a) and the Vargas Era (2000), as well as on the history and historiography of the Estado Novo (1999b).

Since the 1960s, therefore, work on the topic of political thought/conservative intellectuals has been widely developed, ranging from approaches that sought to identify intellectual lineages in the history of Brazil (such as SANTOS (1978,1970,1967), LAMOUNIER (1977), BRANDÃO (2007) and VIANNA (2004)), studies by specific authors, such as Maria Teresa Sadek's book on Octávio de Faria (1978) or more recently the research of Rogério Dultra dos Santos on Francisco Campos (2007) and studies on political concepts (FERES JÚNIOR and JASMIN, 2007). The vast majority of these studies were restricted to the period from the end of the nineteenth century through to the 1950s. Therefore, this set of important works has not exhausted the topic of conservative thinking and intellectuals, especially vis-à-vis the second half of the twentieth century. It is

\footnotetext{
${ }^{6}$ Among many others: Lynch $(2016$; 2013), Ricupero (2004), Ferreira (1999), Fernandes (2018, 2008), Hollanda (2012, 2009), Coser (2008). For a more complete list of submitted theses in the area of Brazilian Political Thought, cf. Lynch (2016, pp. 100-105).
} 
significant that of the 12 chapters of the excellent book 'Revisão do pensamento conservador', edited by Gabriela Nunes Ferreira and André Botelho (2010), none addresses the period from the 1960s onwards ${ }^{7}$. Thus, I hope to bring a contribution from a perspective that lies at the intersection of Brazilian Political Thought and the History of Intellectuals.

Three points will be emphasized in this analysis of the lectures given by conservative intellectuals at the ESG. The first is the presentation of Brazil's history through the lectures of Pedro Calmon (1980) and Josué Montello (1977). The second point is divided into two parts. First, the analysis, based on the lectures by Austregésilo de Athayde (1963) and Vianna Moog (1971), considers the appreciation of the history of the 'formation of the people as a result of the mixture of the three races' made on the basis of a 'Brazilian culture', the main characteristics of which are cohesion and harmony, followed by an analysis of the definition of the rather vague notion of the 'Brazilian man'. The final point deals with the background to how the academy defined the characteristics and 'psychology' of the Brazilian people based on the lecture delivered by Cândido Motta Filho $(1977,1968)$.

Pedro Calmon, Josué Montello and the history of Brazil: optimism and the birth of 'national sentiment'

Conservative intellectuals approached the problems related to the 'psychosocial field' of the National Security Doctrine through the history of Brazil. A somewhat linear interpretation of Brazil's history is presented in the lectures given by Pedro Calmon (1980) and Josué Montello (1977). The starting point is the arrival of the Portuguese and the ensuing colonization, passing on to a separation with the Metropolis that was free of conflict, and continuing its march towards the country's inexorable destiny as a 'great power'. This optimistic reading of Brazilian history was not new. Pedro Calmon himself wrote an important work published in 1933, the approach of which is distinguished by 'naive optimism'. This expression was coined by José Carlos Reis (2006), who also indicated an 'ultraconservative optimism'

${ }^{7}$ Only the chapter written by Christiane Jalles de Paula (2010), on Gustavo Corção, reaches the 1960s. 
present in a number of authors that impregnated the official discourse under the military regime ${ }^{8}$.

Pedro Calmon, born in Bahia in 1902, was from a celebrated oligarch family, numerous members of which became politicians after Independence. He began studying law in Salvador in 1920 and, like other intellectuals of his generation, began to write for the press before graduating in 1924. He was then appointed curator of the National Historical Museum and, in 1926, 'speaker' at the IHGB, before becoming a full member in 1931 and president from 1968 to 1985 . He started his political career during the elections of 1927, when he was elected State deputy. In 1934, he won a seat in the National Assembly where he served until 1937. During the dictatorship of the 'Estado Novo', he focused on academic activities: in 1938 he became Chair of Constitutional Law, Dean of the Faculty of Law of the University of Brazil $^{9}$ and, from 1941, joined the recently created Pontíficia Universidade Católica of Rio de Janeiro. In 1948 he was appointed president of the University of Brazil. He briefly headed the ministries of Education and Health at the end of General Eurico Gaspar Dutra's presidency, and again under Juscelino Kubitscheck, albeit on an interim basis. During the military dictatorship, he took charge of the negotiations that would culminate in the Medici Government donating the building that went on to become the new headquarters of the IHGB ${ }^{10}$.

The lecture entitled 'The Cultural Evolution of Brazil', which Calmon gave on September 06, 1974, presented an evolution of history linked to the genesis of a culture and an awareness of Brazilian nationality. The structure of the text was relatively pedagogical. Brazil was born at a time when the renaissance of classical humanism and optimism had already taken place. According to Pedro Calmon:

${ }^{8}$ This phenomenon was studied by Carlos Fico, who demonstrated the link between a political fact the propaganda of an authoritarian regime that was atypical in the Brazilian case and structured in a broad system - and a long process, namely, the attempt to elaborate an optimistic reading of the history of Brazil; cf. Carlos Fico (1997).

${ }^{9}$ The University of Brazil would later become the Federal University of Rio de Janeiro.

${ }^{10}$ The biographical information on Pedro Calmon was taken from the Dicionário Histórico Biográfico Brasileiro (entry 'Pedro Calmon'. Available at: http://www.fgv.br/cpdoc/busca/Busca/BuscaConsultar.aspx. Viewed on January, 14, 2020) and also from his memoir (CALMON, 1995). 
It is the bedazzling confidence in Brazil. Embedded in a further sense of security, of patient optimism, of a generous and gentle certainty, such as that which derives from faith. It is the consolatory prescience of the future. In this state of geographical sufficiency, it is the idea of paradise that mystically prevails; not that which was lost by theologians, but that which was found by travelers; an earthly paradise either in the landscape or in innocence: nature and the wild [...] Thus, from the idyllic assumption that Brazil was the true paradise, thence began the messianic prophecy, that everything was predestined for it to become, if not the fifth empire, at least one of the empires of the world (CALMON, 1974, p. 09).

The Independence of Brazil - the 'Brazilian Revolution of 1822' according to Calmon - was a 'cultural event'. The Empire represented 'the instinctive affirmation of nationality' and reinforced institutions linked to culture, which were its very basis: higher education, the press, the library, the theater. This movement of cultural emancipation - in which romanticism played a decisive role - was superior to that of political life, and finally reached 'cultural maturity' in the nineteenth century through:

Comtism, which invaded polytechnic and military education; the sociology, that shook things up in the legal field through to metaphysics, with the 'School of Recife'; soon, cultural anthropology, embedded in the recent patterns of Lombrosian criminology and German psychiatry, with an immediate literary reflex in Sertões, in the prose of the engineer Euclides da Cunha - emerged, imposed itself, and triumphed at a time when the intellectual elite (in open conflict, on the eve of the Republic, with the ruling elite) proclaimed its cultural maturity (CALMON, 1974, p. 12).

This awareness of nationality was a theme followed up on by Josué Montello in his lecture 'The Brazilian Culture', given in 1977. Montello was born in São Luís do Maranhão in 1917. He began writing for newspapers and participated in literary societies. In 1936, he settled in Rio de Janeiro where he collaborated on several literary magazines. From the 1940s, he began his climb through public positions related to culture, and in 1947 was appointed director-general of the National Library; he also directed the National Theater Service. In 1953, at the invitation of the Brazilian Foreign Office, he oversaw the chair of Brazilian Studies at the Mayor National University of San Marcos, in Peru (1957); at the University of Lisbon (1958); and at the University of Madrid (1959). During the military dictatorship, between 1969 and 1970, he held the position of cultural advisor to the Brazilian 
Embassy in Paris, and from 1985 to 1989, he was Brazil's ambassador to Unesco. Montello was a prolific novelist and journalist, writing dozens of novels, and maintaining a weekly column in the 'Jornal do Brasil' between 1954 and 1990.

In his lecture at the ESG, Montello initially stated that language is the most complete cultural expression of nationality and that it is inseparable from literature. From this point, he proposed an approach vis-à-vis the formation of Brazilian nationality and culture with exclusive reference to literary texts. The first part of his lecture, however, was not devoted to literature, but to the Portuguese language itself and to the polemics that its uniqueness in relation to Peninsular Portuguese still provoked in the twentieth century. It is no coincidence that Montello merged what he termed the 'rebellious generation of 1922' and national awareness concomitantly with the first centenary celebrations of Independence and acceptance of the peculiarity of the Portuguese language spoken in Brazil, as defended by Graça Aranha (1925) in his famous lecture 'O Espírito Moderno'. At the time he was writing, in the 1970s, this problem of language was no longer an issue, since what Josue Montello called the 'creative experiments' conducted by such literary figures as Mário de Andrade, José Lins do Rego, Guimarães Rosa and Gilberto Freyre had led to their being universally accepted as members of the lusophone canon.

He then turned to the question of 'national sentiment' and demonstrated that it had already been present in the first literary texts written in Brazil. These lectures demonstrated the political role that these intellectuals attributed to literature. If they remind us that the 'Inconfidência Mineira' was a 'literary conspiracy', then it was a 'purely literary' text that revealed an overall view of the Fatherland, indispensable to the political act of Independence. Throughout Brazil's evolution, then, fiction has accompanied the birth of nativist sentiment, the awakening of awareness of nationality, the gradual affirmation of a tropical civilization and the pathways that lead to a national culture.

Montello (1977) began with the celebrated letter from Pero Vaz de Caminha to Manuel I of Portugal and the description of the land therein, followed by an antiPortuguese satire by Gregorio de Matos. Father Manuel da Nóbrega was then enlisted to discuss the conflicts between European and indigenous Brazilian cultures, as was Gonçalves Dias, who recognized himself as being indigenous and 
wrote poems condemning slavery. It was in the book 'História do Brasil' by Frei Vicente de Salvador, published in 1627, that Montello (1977) found the first instance of praise of the 'tropical man'. These early documents expressed a precocious nationalism. However, according to Montello (1977), it was only with 'O Uruguai' and 'O Caramuru', published respectively by Basilio da Gama in 1769 and Santa Rita Durão in 1781, that we obtain the first global view of Brazilian nationality before the advent of Romanticism, that literary growth hormone of national sensibility.

As may be observed, in their lectures at the National War College, conservative intellectuals approached the history of Brazil in a very deterministic manner, with a well-defined starting point and an inexorable trajectory towards its destiny as a great power. For Calmon (1980), Brazil's 'disadvantage' in relation to Europe was surpassed by what the land and geography could offer. According to him, there was a fundamental difference between Europe and America: if time engendered the Nation in Europe, the State being the result of its maturity, then in America it was the territory that determined the Nation, and the State would be the result of integration (CALMON, 1980, p. 03). 'Integrating' was a key word for the military, an important task they took on as their responsibility. Culture, on the other hand, was to evolve from the outset, which enabled a speedy identification with what they called 'nationality' or 'national sentiment'. This search for the origins of 'national sentiment' seems to have been a goal of great importance: the awareness of a set of common values that provides a feeling of belonging to a nationality. As is well known, the search for the genesis of a national sentiment has long existed and is linked to the desire to constitute a certain image of the Nation. Thus, for successive generations of intellectuals attempting to understand 'Brazilianness', 'what we are' or 'why the country works or does not work' has been related to the problem of 'national sentiment' (FIC0, 1997, p. 28). During the dictatorship, in the second half of the twentieth century, evoking the origins of 'national sentiment' as a way of explaining the greatness of the present was very much in vogue among conservative intellectuals. Finally, the notion of optimism with regard to the fate of Brazil is a crucial aspect that helps us to understand the proximity of worldviews between conservative intellectuals and those in charge of the regime. It was this optimism, in the midst of the dictatorship, that enabled Calmon to conclude his lecture in the following manner: 
It was not by chance that [Brazil] became organized; nor was it that success was achieved over the negative elements that threatened it. It was built, rebuilt, and was satisfied with those who taught it to be both federatively singular and multiple, intellectually free and creative, morally human and Christian, politically democratic and generous, culturally what in reality it is, the Brazil-Brazilian (as Eça de Queirós wrote to Eduardo Prado) searching for his own reflection in the troubled mirror of the waters, above them the Roman arch of knowledge, on the mossy bed across which the river runs. Allow me to complement this: it has flowed from its former springs, and will flow into the blue seas ... This is to repeat the prediction of those who foresaw the country's dimensions (Grandezas do Brasil, in 1618!) and to imagine that the shallow brook of yesterday will be the ocean of the future! (CALMON, 1974, p. 11).

\section{The 'Gilbertization' of Brazil: the formation of the people, miscegenation, cohesion and harmony ${ }^{11}$}

The two authors analyzed in the previous section deal only marginally with one aspect of the national history, which has become one of the main issues of intellectual debate since 1930: the problems of the people, their formation and their psychology. The Brazilian Nation could not be constituted without the people, from whom it was hoped that the national identity would be born. Therefore, it was essential to know its origins, its formation, its psychology, and its customs. In 1933, Gilberto Freyre published 'Casa Grande \& Senzala', one of the masterpieces of Brazilian literature, which presented a history of the formation of the Brazilian people as a result of the harmonious acculturation of the three races, possessing characteristics such as docility, sentimentality, cordiality and a conciliatory spirit.

This paper will not embark upon yet another analysis of the content or importance of this work, nor its impact on the intellectual environment or the mentality of the time, since this has already been undertaken by numerous scholars. However, it is useful to note the rupture it represents in relation to previous interpretations - especially in relation to the racial problem - before this paper sets out towards its goal, which is to analyze the circulation and diffusion of its interpretation during the 1960 s and 1970s. It is also important to stress that Gilberto Freyre's (2013 [1933]) celebrated work, together with those of Sérgio Buarque de Holanda (1936) and Caio Prado Júnior (1942) mentioned below, will not

${ }^{11}$ The expression 'Gilbertization' ['gilbertização' in Portuguese] is taken from Carlos Guilherme Mota (2010).

(2021) $15(3) \quad$ - $\quad$ e0001-12/32


be treated here as 'natural classics'. Nonetheless, discussion on the 'construction' of these works, as well as the 'travail de l'œuvre', i.e., the various reinterpretations to which they have been subjected and the impact that they have had on their different reception contexts, are outside the scope of this paper ${ }^{12}$. This discussion is centered around how they were used by intellectuals in political struggles.

Between the end of the nineteenth century and the beginning of the twentieth, Brazilian intellectuals published important works influenced by fashionable theories in Europe - Auguste Comte's positivism, Spencer's social Darwinism, and evolutionism. These intellectuals chose the notions of environment and race in order to understand Brazil's specificity and its 'backwardness' in relation to the general evolution of Western societies. Their analytical framework is fairly pessimistic: geography and race were the cause of Brazil's backwardness. According to this interpretation, all the inherited disabilities of the biological patrimony would include, amongst other items, apathy, moral and intellectual imbalance and inconsistency.

It was within this context that the 1930s saw the publication of some innovative works, 'essays on the interpretation of Brazil', the importance of which may only be compared, according to Francisco Weffort (2006, p. 277), with the Romanticism and Indianism of the nineteenth century. If Caio Prado Junior and Sérgio Buarque de Holanda contributed to bringing the people into account as being essential actors in political history, it is 'Casa Grande \& Senzala' that represents the most complete break with the past. Freyre introduced into Brazilian thought a detailed description of the relationship between Blacks, Whites and Indians and the many mixtures thereof. The change of perspective was radical: unlike his predecessors, he presented miscegenation in a positive light and the 'mestiço' as an advantageous synthesis. This interpretation of the history of Brazil was an inexhaustible source for authoritarian regimes concerned with their role in the construction of nationality. For the ideologues of the 'Estado Novo', as well as for those of the military dictatorship, Freyrean exegesis offered the vision of

\footnotetext{
${ }^{12}$ With regard to this discussion, I would draw attention to the works of Feldman (2016) on 'Raízes do Brasil' by Sérgio Buarque de Holanda; of Pallares-Burke (2005) on Gilberto Freyre's 'CasaGrande \& Senzala'; and of Iumatti (2018) on 'Formação do Brasil Contemporâneo' by Caio Prado junior.
} 
a harmonious Brazil, with its own identity and an authentic 'Brazilian culture'. These two authoritarian regimes of twentieth-century Brazil appropriated several elements of this analysis: it permeated the official discourses and served as a guideline for cultural policies.

This interpretation was resumed by Austregésilo de Athayde in a lecture at the National War College in 1963, amidst a context of strong political radicalization. Born in 1898 in Pernambuco, he moved to Rio de Janeiro in 1918. Shortly after his arrival he found a job in the newspaper 'A Tribuna' and in the following decades became one of the most renowned journalists in the country, writing daily and running a number of newspapers until his death in 1993. After the Vargas government fell in 1945, Austregésilo de Athayde, a self-proclaimed liberal since the 1920s, joined the right-wing party União Democrática Nacional (UDN) and became an enthusiastic 'udenista'. It was also during the 1950s that Athayde entered the ESG, initially as a student, then as a lecturer. The ESG played a crucial role in Austregésilo de Athayde's ties to the military elite that led the 1964 coup (SANDRONI and SANDRONI, 1998, p. 517). Finally, he was elected to the ABL in 1951 becoming, from 1959, the institution's president and being reelected over more than thirty years until his death.

In the two dozen pages in which Athayde sets out to define some of the psychological characteristics of Brazilian people, the first significant point deals precisely with the problem of miscegenation. It may be said that Athayde 'radicalized' Gilberto Freyre's view by asserting that the Brazilian people were 'the synthesis of humanity', since the Portuguese, before mixing with Blacks and Indians 'without any prejudice', carried with them the blood of the 'Iberian, Celtic, Greek, Phoenician, Roman, Visigoth, Jewish, Arabic, French, English, Flemish and Castilian' peoples. In short, the blood of all the peoples who had crossed the Iberian Peninsula. Thus, in Brazil, according to Athayde:

The three races have come together to form the Brazilian people, creating blood ties that the millennial preparation of the inhabitants of the peninsula made easy, through a long and constant process of miscegenation, with no repugnance on the part of the white man, originating from physical or psychological reasons, towards procreating with the indigenous and the African (ATHAYDE, 1963, p. 38). 
Athayde continued his lecture stating that 'national sentiment' had been formed since the early days of colonization. He based his observation on literary works such as 'Prosopopeia' by Bento Teixeira Pinto and the verses of Gregorio de Matos, but also invoked struggles, such as the 'Emboabas' and 'Mascates' War or the conflict with the Dutch in the seventeenth century. The expulsion of the latter would be, for Athayde, "proof of national sentiment and of the profound unitary instinct which the Portuguese transmitted to their descendants in America" (ATHAYDE, 1963, p. 41). According to Athayde, national unity and solidarity between races was concomitant, the latter being the 'dynamic principle of the unity of nations'. One section perfectly expresses the idea of harmony and the absence of conflict that the conservative political and intellectual elites constantly attempted to present as inscribed in the history of Brazil:

The society, which is organized in the south is not so diverse, either in its ethnic composition or in the characteristics of its psychology, as that laying down roots in the North and Northeast. Here we have the presence of the three races, the white, the indigenous and the black, who form a miscegenation in the same spirit of tolerance and sympathy, with no repulsion or prejudice, with the same kindness of treatment given to the slaves that so impressed the travelers of the time, and those who most observed slavery in Brazil, some of whom were mentioned by Gilberto Freyre, are truly astonished at the harmony between masters and slaves, and state that the condition of the black population in Brazilian senzalas is sometimes much higher than that of free workers in England [...]. In the gentle attitude of the masters towards the slaves, in the very amenity of the temperament of the black minas, nagôs, haussás, from Sudan, of the Angolans, the Congolese and Cambindas, and a score of other African races, as well as in the natural sweetness of the indigenous, in the sentimentality and in the mystical penances of the three races, are the roots of Brazilian social democracy (ATAHYDE, 1963, p. 42).

Two distinct moments may be clearly identified in this lecture: the first, which ends with the quotation above, is where Athayde drew upon Brazil's social and economic history to emphasize the 'harmonious acculturation' of the different constituent ethnicities of the Brazilian people and their 'psychosocial characteristics': docility, sentimentality, warmth, affectivity, etc. These two elements - harmonious acculturation and psychosocial characteristics - are at the 
origin of 'national unity' and 'Brazilian social democracy'. In a second moment of his lecture, Athayde discusses the factors that may compromise 'national unity' and threaten 'internal security'. It is interesting to note how the president of the Brazilian Academy of Letters creates the link between the social history of Brazil and the threat posed by communism and, more generally, Marxism, to national security and unity.

First, he approached the study of another famous intellectual, Alceu Amoroso Lima $^{13}$, who argued that there were four 'levels of culture' in Brazil: an 'Atlantic' culture, present in large cities; a 'mixed' culture, present in small towns or wellorganized, developed farms; the lowland culture of less developed farms and the hinterland; and, finally, the 'primitive' culture that dominates in untamed regions. According to Athayde, at the time of writing in 1963, it was no longer possible to differentiate between the first two cultures, the 'Atlantic' and the 'mixed': over the last thirty years the 'mixed' culture had incorporated the mentality of the large urban centers and everything that concerned the expansion of ideas, arts, tastes, entertainment and comfort. The problem was placed at the level of the lowland culture, of the "illiterate masses of weak economic weight, who are not integrated into the life of the national community because of the marginality of a purely vegetative existence" (ATHAYDE, 1963, p. 44). This mass had suffered a 'paralysis of its evolutionary process', becoming an 'inert mass' that, at any moment, could once again become dynamic; "for this reason, it deserves special attention because of the danger it poses to the security of the nation" (ATHAYDE, 1963, p. 45). This sentence reveals a form of thinking true to the conservative spheres of the 1960s: the risks to security and unity of the nation were to be found in the most disadvantaged classes, for it would be through them that communism would infiltrate the body politic. They therefore deserved 'special attention'. This was an ambiguous passage in the lecture: this 'special attention' meant, on the one hand, help and give them the necessary minimum; but, on the other hand, monitor them and, ultimately, repress them so that Brazil would not suffer the same fate as in China, where 'the masses were touched by a revolutionary

\footnotetext{
${ }^{13}$ In the text of the lecture, Athayde does not specify the study by Alceu Amoroso Lima to which he
} refers. 
force that fed two decades of civil war that finally delivered them into the hands of communism'. For Athayde, if the masses of the lowland culture did not adhere to communism, it was because they "possess in the essence of their minds the same basic stimuli of mixed and Atlantic culture in the temperament of man and in the principles of his moral formation" (ATHAYDE, 1963, p. 48).

According to Athayde, it was the historical constitution of the people and their psychosocial characteristics that prevented their adherence to communism, although the risk was still present. Commonality of language and religion would not be sufficient to guarantee the unity of the country:

There is a lot of religiousness, attachment to the religious feelings gathered within the family tradition. One wonders whether this religiosity will suffice as a defense against Marxist ideology, whether we should count on the Catholicism of the people as an element of security against communism. I harbor doubts regarding this [...] Communist propaganda is not based on the denial of dogmas and on attacking religion. Communist agents seek other ways of reaching the spirit of the masses and of taking possession of it, including using the Christian religion in its primitive forms as an argument for the communist ideal [...] Furthermore, the democratic temperament of the people is not a sufficient shield. Religiosity and the political sense of equality and freedom predispose opinion to fight against regimes that harass or suppress the fundamental rights of the human personality and place the Brazilian people in the face of the world conflict between Western democracies and Soviet totalitarianism forthrightly alongside the former, as has already occurred in the two great wars of the century. The national mentality inclined towards sentimentality, sweetness and tolerance, goes against the forms of violence on the part of the state, and will always be a strong guarantee against the implantation of police states and oppressive regimes. Individualism, reluctance to join group activities, aversion to rigid discipline, a natural awareness of American liberty, the spirit of independence that makes man prefer the life of the thin dog of fable, misery and hunger, rather than the satisfaction of the fat dog on the leash, such innate tendencies, linked much more to the ancestral experience of the three races than to acquired ideas, seem to me the most important elements that protect against oppressive regimes. They are virtues and defects with which the Brazilian people have been peacefully carrying out their revolution, reaching the stages of their destiny without bloody struggles, through white revolutions, which have avoided stoking resentments between classes, racial groups or regions (ATHAYDE, 1963, p. 49).

The analysis of Austregésilo de Athayde's lecture illustrates the political use of a certain conception of 'Brazilian culture' defined as democratic, heterogeneous and plural. A 'Brazilian culture' also defined by 'happy miscegenation', a result of the 
'harmonious acculturation of the three races'; the 'absence of conflict'; 'unity in diversity'; 'sentimentality, docility and cordiality'.

\section{The 'Brazilian man' and his psychology}

The 'Brazilian man' and his 'psychology', problematics merely mentioned by Austregésilo de Athayde in his lecture, were also at the center of two other lectures by renowned conservative intellectuals, Cândido Motta Filho and Clodomir Vianna Moog. They occurred respectively, on May 16, 1968, just over a year after the investiture of the second general-president, Costa e Silva, and seven months before the AI-5 decree; and on September 08, 1971, at the height of the Médici administration, a moment of euphoria within the country, of economic growth, but also of much repression.

Vianna Moog, born in 1906 in Rio Grande do Sul, was a lawyer, novelist and essayist. He became a civil servant before graduating with a bachelor's degree in law in 1930. He engaged in the political movements of the decade, such as the Liberal Alliance that brought Vargas to power, but two years later was fighting against him in the Constitutionalist Revolution. It was also during this decade that he began writing for newspapers. It was after the 1937 coup that Vianna Moog began to acquire a name as an author. From the 1940s, while advancing his career in the civil service, Vianna Moog began to expand his activities as a journalist, writing in various newspapers both in Brazil and abroad, while also continuing to publish essays and novels. These include 'Bandeirantes e Pioneiros', a well-known comparative essay on the history of Brazil and the United States published in 1954, and a biography of Abraham Lincoln, published in 1968. From the mid-1950s Vianna Moog was appointed to several key diplomatic positions, the most noteworthy of these being as Brazilian representative to the UN and the OAS. From the mid-1940s, Vianna Moog was already a recognized intellectual in conservative circles, a recognition sanctioned by his election to the ABL in $1945^{14}$.

14The biographical information on Vianna Moog was taken from the website of the Brazilian Academy of Letters. Available at $\leq$ http://www.academia.org.br/academicos/vianna-moog/biografia $\geq$. Viewed on January, 21, 2020. 
In his lecture at ESG, Vianna Moog proposed to identify the moment in which the term 'Brazilian' first acquired the meaning related to the idea of belonging to a nationality. According to Moog (1968), this did not occur before the eighteenth century. Seen from the outside, a Brazilian was designated as one who worked in the pau-brasil industry; seen from the metropolis, it was applied those who returned to Portugal after getting rich in the colony. In fact, the goal of everyone was to become wealthy, return to Portugal and, under no circumstances, except for those who had no choice, stay in the colony. At a certain period in time, however, a change took place: those who had been born in Portuguese America decided that they did not want to leave, and this was the starting point for the configuration of the 'Brazilian'. There were also cases of Portuguese who had been born in the colony and went back to Portugal to study but found that they did not feel at home and consequently desired to return to Brazil at all costs. Vianna Moog symbolically chose the poem by Gonçalves Dias as the moment the Motherland was born, in which the term 'mazombo' appears, a pejorative term for Portuguese descendants in Brazil that since gradually fell into disuse.

The most interesting point in examining Vianna Moog's political character comes at the end of his lecture, at the moment he defines the 'Brazilian man'. He asked his audience: "Dear gentlemen, what does it mean to be Brazilian? How do we distinguish a Brazilian?" (MOOG, 1968, p. 16). He argued that he was not searching for a definition that could be found in the dictionary, i.e., regarding those who had been born in Brazil or who had legally acquired citizenship. The Brazilian he sought to define was one that was 'culturally' Brazilian, one that was 'integrated' into Brazilian culture. The answer to his question was based on several texts by Gilberto Freyre, such as a 1941 lecture entitled 'Uma cultura ameaçada' [A Threatened Culture] (1940a), which he cited in his text, and certainly, although they were not cited, a set of lectures published under the title ' 0 mundo que o português criou' [The World that the Portuguese Created] (1940b), another publication from the 1940s. For Vianna Moog, at the root of 'brasilianidade', one would find 'lusitanidade' and, as a consequence, the Brazilian must be 'lusitanizado'. However, this should not be misunderstood: 'lusitanized' is not the same as 'lusitanian' but rather one whose being comes from the depths of Latinity. Anyone who failed to 
understand this 'fundamental truth' would never understand the characteristics of a Brazilian and the Brazilian culture. Moog examined two of these characteristics.

The first, and fundamental characteristic, was the Brazilian's ability to 'assimilate, beyond the past of the Lusitanian, the African and the Indigenous', which neither the Hispanics nor the Americans could do. We owe this 'capacity for assimilation' precisely to this Lusitanity, totally incompatible with any radicalism or fanaticism. The second characteristic, Vianna Moog saw as the enormous quality of the Brazilian political elites: their vocation to anticipate the pressures of the masses to promote the necessary political and social reforms without violence. He then analyzed certain transitional moments in the history of Brazil, which occurred 'at the right moment and without bloodshed', which would not have pleased those he ironically designated as 'certain patriots' in reference to the communists:

There will surely be many people in our midst who do not like this style and who may have preferred that our independence, for example, had been won in the bloody manner that it was - very prematurely, in my view, by the Spanish-American republics - and not handled at the right moment, neither before nor after, with the aptness, the touch, the magic touch and, at the same time, the firmness of José Bonifácio. There will also be those who deplore the fact that abolition did not cost us a million lives, which is approximately how much the civil war must have cost the American people. It is possible that these same people disapprove of our boundaries demarcated by mixed commissions and international arbitration tribunals, with hand and sight maps, in the style of the great Rio Branco, and not by force, at the will of the winner and forced complacency of the loser. There will be no lack of those who refuse to join the Republic in the manner in which it was proclaimed, and in the 1930 revolution, for the way in which it gave workers what, in the opinion of these patriots, they should have conquered by fire and sword. These patriots will probably continue to mumble, because the structural reforms that Brazil has undergone since the 1964 revolution, especially nowadays, are not being sufficiently cemented with the blood of soldiers, students, workers and peasants, as they the rules of their booklets dictate (MOOG, 1968, p. 20).

At this moment, Vianna Moog made a distinction between two categories of 'Brazilians': the 'real' Brazilians and those who were 'no longer' or 'not as yet' Brazilian, i.e., those who had not lost their citizenship, but rather their 'lusitanity': 
But these, let's face it, are not yet Brazilian, or are no longer Brazilian. They would still be mazombos or Brazilians who, without losing their citizenship, have lost their ballast of Lusitanity. In both cases, they are archaic. Immersed in Darwin or Karl Marx, two personalities who, each in their own way, always felt dreadfully oppressed by the past, unfamiliar with any style and language other than the jargon that brings forced discourse to expressions such as class struggle, survival of the fittest, labor exploitation, natural selection, economic factor, dialectic materialist or simply dialectic, scientific socialism, alienation, radicalization and pressure, did not realize that the world, with the advent of atomic energy, began to live within another era and this new era converted war, with which all problems were erstwhile simplified, into an impossibility, in which utopia, the political and social philosophies inspired by Darwin and Karl Marx became suddenly anachronistic... (MOOG, 1968, p. 20).

And Moog concluded his lecture in the same mood of optimism and euphoria that marked the first half of the 1970s: "And do you wish to know what the new era came to be? The style, the aspirations and the values of lusitanity, that today find in the Portuguese-Brazilian culture their strongest expression" (MOOG, 1968, p. 21).

This is an exemplar of the connection between a particular interpretation of Brazil and of 'Brazilian culture' and the project of the military regime. Between the two, we find the role of the intellectual, a fundamental element of connection. As we have already mentioned, the interpretation was that elaborated by Gilberto Freyre, who, although he preceded the dictatorship by several years, remained hegemonic in the following decades. It is important to note that in the years that followed the publication of 'Casa Grande \& Senzala', its author did not cease to reflect on Brazilian culture, which he inserted into a larger whole, which was the 'Luso-Afro-Brazilian culture', as may be observed particularly with the publication of ' $\mathrm{O}$ mundo que o português criou'. The lectures brought together in this book defended a vision of a supposed cordial specificity and of the great ability of the Portuguese to adapt to the tropics, with their particularities as agents of an ethnically democratizing miscegenation ${ }^{15}$.

\footnotetext{
${ }^{15} \mathrm{At}$ the moment Gilberto Freyre published this series of lectures, he was already an acclaimed author, not only thanks to 'Casa Grande \& Senzala', but also for publishing two of his most important works: 'Sobrados \& Mucambos', in 1936, and 'Nordeste', in 1937. One final comment: this 1940 book was very well received by the Salazar dictatorship in Portugal, considered by several commentators as a compliment of Portuguese colonialism.
} 


\section{bpsr}

However, at the time of Vianna Moog's lecture at the National War College, on September 08, 1971, a major conflict took place in the intellectual field. At the moment in which he so convincingly expounded a definition of the 'Brazilian man' based on the 'fundamental truth' of 'lusitanism', important works in the Luso-AfroBrazilian world were being published that questioned the idea of a 'Luso-tropical' culture characterized by cohesion and harmony. On a political level, Portugal was going through a period of profound changes. Less than one year after Salazar's death, with the Portuguese colonies of Africa in the midst of a civil war that would ultimately lead to independence, but still before the Carnation Revolution, Portugal was on the eve of the collapse of the 'world that the Portuguese created'. This shows the chasm between Vianna Moog's purely ideological discourse and the international situation at that time.

Finally, the way that Moog chained the transitional moments in Brazilian history is interesting: from Independence to the coup d'état of 1964 - which he calls the 'Revolution of ' 64 '. He presented these as being necessary and cleverly led by a political elite who knew how to act without violence. This was the correct way to carry out the necessary reforms; those who disagreed with the stages of this process, whether it was Independence in the nineteenth century or the coup d'état of 1964, were not 'real' Brazilians.

The 'Brazilian man' was also the theme of the lecture by Cândido Motta Filho entitled 'The basic elements of nationality - man', presented on May 16, 1968 and divided into four parts: 'Historical man', 'Physical man', 'The psychology of the Brazilian man' and 'The Brazilian man in the social plane'.

Cândido Mota Filho was born in São Paulo in 1897 and earned a bachelor's degree in law from the Faculty of Law of São Paulo in 1919. Shortly after graduation, he simultaneously began a career in the judiciary, journalism and politics. In 1922, Mota Filho played a significant role in the 'Semana de Arte Moderna'. Together with Cassiano Ricardo, Menotti del Picchia and Plínio Salgado, he joined the 'VerdeAmarelo' group. A little later, along with most of the other members of the movement, he founded the 'Bandeira' group, which valued strong government based on national traditions, discipline and social hierarchy. His political and intellectual activity remained intense during the 1930s. Mota Filho soon opposed Vargas and 
supported the 1932 Constitutionalist Revolution. He was elected state deputy for Sao Paulo in 1934, and after a brief period of opposition to the Vargas dictatorship, later accommodated himself to the regime. The following year, he became head of the powerful Department of Press and Propaganda (DIP). After the 1945 democratization, Mota Filho continued to occupy high political positions. He was chief of staff of the Minister of Labor during the presidency of General Eurico Gaspar Dutra; in 1954 he became Minister of Education; in 1956 he was appointed Minister of the Supreme Federal Court (STF). Short after the coup, in 1964, he assumed the chair of the Higher Electoral Court (TSE) ${ }^{16}$.

According to Cândido Motta Filho, in order to understand the 'Brazilian man' it was essential to approach him from several angles. This was a very similar interpretation to those proposed by the other intellectuals, Pedro Calmon and Vianna Moog in particular, in the first part entitled 'the historical man' [0 homem histórico]. In other words, the arrival of the Portuguese, their civilizing role, the birth of national sentiment and the beginning of Brazilian history as a continuation of Portuguese history: "Conditioned, as Gilberto Freyre says, by monoculture and slavery, supported, compressed and repressed by greed for exploitation, the Brazilian writes his history as the continuity of Portuguese history" (MOTTA FILHO, 1968, p. 09).

In the second part, Cândido Motta Filho discusses the physical' conditions of the Brazilian man and argues that this examination should not be limited to the study of 'the elements that compose it' but should extend to a more general field of analysis. Whereas during Romanticism the Brazilian man presents only some ideal and symbolic characteristics, today he would acquire a 'physical' definition. It is at this moment that the lecturer examines the issue of miscegenation. According to Motta Filho, despite an 'incomplete' definition, it was possible to trace certain singularities from the races that populated the country:

The white man with his Western activism, with his mercantile and civilizing spirit, in the discovered land, makes an extraordinary effort, astonishing even, with the help of the indigenous and the imported black

\footnotetext{
${ }^{16}$ The biographical information on Cândido Mota Filho was taken from the 'Dicionário Histórico Biográfico Brasileiro' (entry 'Cândido Mota Filho'. Available at <http://www.fgv.br/cpdoc/acervo/dicionarios/verbete-biografico/mota-filho-candido>. Viewed on January, 20, 2020) and also from his memoirs (MOTA FILHO, 1977).
} 
population. But this white man comes from Portugal, with its own religion, with its language, its uses and customs, still burdened with the multiplicity of its racial antecedents. Within them cohabit Christians, Arabs, Jews, Goths, who crossed with one another and crossed again in the Peninsula and, with their economic, social and political processes, gave features to the Portuguese man [...] The indigenous almost disappeared in the face of the impetus of exploration. But they persisted in miscegenation, more defeated than convinced, for the caboclo behavior was soon felt, in resistance to foreign innovations [...] And if the Portuguese are multiple, in racial physiognomy, so were the indigenous and the black population [...] The truth is that the physical type of the Brazilian is a product. In it there are different bloods and different souls. Each of us carries commitments to living and extinct races (MOTTA FILHO, 1968, pp. 14-17).

However, it is the fourth part of Cândido Motta Filho's lecture that is the most interesting and which brings us to the final part of this analysis. Motta Filho, also a member of the Brazilian Academy of Letters and a Justice of the Federal Supreme Court during the dictatorship, proposed to define the 'psychology of the Brazilian man'. He stated that if one were able to speak of an individual psychology, one may also speak of the psychology of a people, be it German, American or Portuguese, defined by habitual coexistence, by social institutions, in the process of language or religious beliefs. All this enabled him to capture his 'nature', his 'proper behavior'. And what would these characteristics be? According to Motta Filho:

\begin{abstract}
...extreme sensitivity, large-scale imagination, spontaneous cordiality, predisposed indolence, innate mistrust, rapid comprehension, a certain lightness of mind, to which Alberto Torres has already referred, inconstancy in undertakings, puerility, fondness for novelty, religion without much religiousness, politics without conviction, unmotivated lack of ambition, a certain horror of dogmatism, malice in small calculations, a sensual view of things and the world, fear of hidden things and courage when confronted with visible danger (MOTTA FILHO, 1968, pp. 14-17).
\end{abstract}

If he revised some of these characteristics, the meanings of which, at times, were not particularly clear, he analyzed one of them in much greater detail, that which he called 'spontaneous cordiality'. The concept of 'cordiality' had become famous after Sérgio Buarque de Holanda had used it in his classic 'Raízes do Brasil', first published in 1936. At the time of publication, Buarque de Holanda wanted to understand the process of political transition experienced by Brazilian society in the 
1930s, to identify what past was being overcome and what future could be glimpsed. As stated by Brasilio Salum Júnior (2004, p. 250), the objective of Buarque de Holanda went beyond a simple reconstruction of the Brazilian identity: the proposal was much more complex, since the objective was to reconstitute the 'traditional' Brazilian identity, an archaic one, as one of the poles of the social and political tension of the present, which tended to be surpassed by a society in full revolution. These were the pillars used to construct this problematic identity, fractured and in full development, which Buarque de Holanda proposed to identify.

Part of this book was the subject of a controversy that persisted during the following decades, to the point that even the author himself no longer wished to discuss the matter. This was the notion of the 'cordial man', which appeared at the moment when Buarque of Holanda examined the tensions between the traditional forms of sociability, centered on the patriarchal family, and the models of sociability of the modern world. According to Buarque de Holanda, whose focus of interest lay in the consequences of the primacy of the patriarchal model over the functioning of modern social institutions, an individual formed in a patriarchal environment will have difficulty in distinguishing the public sphere from the private. This is the case of Brazil, a country where the type of relationship resulting from private life - emotional and family ties - prevails into public administration. It is precisely these forms of relationship resulting from rural and patriarchal life that have engendered cordiality. This notion has no connection with manners, civility, or courtesy, since all of this implies the control and subordination of emotions to a set of socially established rules and norms. Cordiality would be precisely the opposite, behavior resulting from emotion and not subject to the norms of social behavior. The definition of cordiality would, therefore, be an attempt to reconstruct, outside the family circle, at the level of society, the same kind of sociability that depends on community ties. Examples of all these would be certain forms of language, expression of religion, rejection of hierarchies, and the search for intimacy when dealing with authorities.

Motta Filho's lecture is an edifying example of the way in which some ideas constructed during the twentieth century on the identity of the Brazilian man were recovered and repurposed by authoritarian regimes. He states that the 'cordial man' comes from the deep connection of the Brazilian man to the earth. Thus, 
He overcomes distances, isolation, the routine of village life, without occurrences and without history, showing himself to be hospitable, making his house the house of his guests, avoiding ceremony with the joy of offering the best room of his house and the best food on his table [...] The habit of receiving guests, which und oubtedly influences the most sensitive sensibility of the Brazilian - is deeply rooted, as experienced by Eduardo Prado on multiple occasions, when, in São Paulo, he crossed the hinterland to reach Bahia [...] The conflicts that arise, which are filled with violence, the famous struggles between families, studied mainly by Oliveira Vianna, cannot erase the content of cordiality, for cordiality is the rule and conflict is the exception (MOTTA FILHO, 1968, p. 20).

When Cândido Motta Filho referred to the 'cordiality' of the Brazilian, he merely reinforced the idea of common sense, and believed that this notion only identified an alleged civility or courtesy in contrast to a conflicting nature. 'Cordiality' was also appropriated by the official discourse of the military regime; its use being thus removed from the intended meaning of the author of 'Raízes do Brasil'.

\section{Conclusion}

This paper has sought to analyze the manner in which conservative intellectuals turned to Brazil's past and to the idea of a 'Brazilian culture' within the context of the Cold War, thus helping to legitimize the Brazilian military dictatorship. My analysis was divided into three parts. First, I demonstrated, through the lectures of Pedro Calmon and Josué Montello, how the conservative intellectuals interpreted the history of Brazil as a succession of linear events, from an origin to a predictable end, to an inescapable destiny as a great power due to geographical conditions - a premonition that was present from the very beginnings of colonization. In addition, everything that distinguishes Brazilians was already present from the sixteenth century, such as the 'national sentiment' [sentimento nacional] present in literary texts, and also the Portuguese language spoken in Brazil, with its singularities, as well as a gradually constituted culture. This reading does not arise 'ex nihilo', on the contrary, it is based on several references: it preceded the coup d'état of 1964 and remained alive during the regime and even after its fall. 
My attention then turned to a crucial aspect for legitimizing the dictatorial State: the issue of the people, the Brazilian culture and the national identity. The lecture by Austregésilo de Athayde is exemplary in its observation of how the concept of Brazilian culture was taken up by a part of the conservative intellectual class during the 1960s and 70s, as it had been conceived and spread from the 1930s, particularly by Gilberto Freyre and the explanatory canons of 'Casa-Grande \& Senzala': according to which this culture was the result of the acculturation of the three 'races'. The political dimension manifested itself forcefully, to the extent that this idea of plurality covered an ideology of harmony already identified and demarcated. These ideas went beyond the racial question and are present in other analyzes, particularly those related to democracy, and which therefore signified heterogeneity, harmony and an absence of conflict. However, what is even more interesting was the way in which Athayde, the famous liberal journalist and president of the ABL used this interpretation to 'prove' the impossibility of a communist regime in Brazil. He stated that it would contradict the cohesion and harmony of Brazilian culture and the very nature of the Brazilian people.

In the final section I considered the way in which these intellectuals described the psychology of the Brazilian people and how they defined the 'Brazilian man'. The lectures given by Vianna Moog and Motta Filho enabled us to observe how the notions created in the 1930s on the nature of the Brazilian, such as cordiality, a conciliatory spirit and sentimentalism, were taken up in the authoritarian context of the 1960s and 1970s.

Under the 'Estado Novo', 'national identity' was completely redefined by valorizing miscegenation, the belief in the docile nature of the people, the exaltation of work and a certain idea of the nation founded on cohesion and cooperation. The lectures analyzed in this chapter have shown that many of these elements were reworked after 1964 by conservative intellectuals, and thus contributed to legitimizing the dictatorship by inscribing it into what they believed the Brazilian tradition to be, presenting the military regime as the only regime capable of preserving national unity and Brazilian culture against the threats posed by Marxism and communism. In this sense, according to these intellectuals, the 
military dictatorship was not only necessary in order to 'save democracy', but was also the savior of the true values of the Brazilian people, Brazilian culture, national identity, tradition and integration, values that would be threatened by any advance of communism.

Revised by Fraser Robinson

Submitted on February 03, 2020

Accepted on August 03, 2020

\section{References}

ARANHA, Graça (1925), Espírito moderno. São Paulo: Ed. Monteiro Lobato. 143pp..

ATHAYDE, Austregésilo (1963), Características psicossociais do povo brasileiro. Conferência proferida na Escola Superior de Guerra. Rio de Janeiro.

BOBBIO, Norberto (1995), Direita e esquerda: razões e significados de uma distinção política. São Paulo: Editora Unesp. 192 pp..

BRANDÃO, Gildo Marçal (2007), Linhagens do pensamento político brasileiro. São Paulo: Hucitec. 220 pp..

BRAZILIAN ACADEMY OF LETTERS (2020), Available at $<h t t p: / / w w w . a c a d e m i a . o r g . b r />$._Accessed on january, 21, 2020.

CALMON, Pedro (1995), Memórias. Rio de Janeiro: Editora Nova Fronteira. 440 pp..

CALMON, Pedro (1980), A cultura brasileira e suas características. Conferência proferida na Escola Superior de Guerra. Rio de Janeiro.

CALMON, Pedro (1974), Evolução cultural do Brasil. Conferência proferida na Escola Superior de Guerra. Rio de Janeiro.

CALMON, Pedro (1933), História da Civilização Brasileira. São Paulo: Nacional/ Brasiliana. Série V. Vol. XIV. 304 pp..

CHIRIO, Maud (2012), A política nos quartéis: revoltas e protestos de oficiais na ditadura militar brasileira. Rio de Janeiro: Jorge Zahar. 262 pp..

COMBLIN, Joseph (1978), Ideologia da Segurança Nacional. Rio de Janeiro: Civilização Brasileira. 251 pp..

COSER, Ivo (2008), Visconde do Uruguai: centralização e federalismo no Brasil. Belo Horizonte/ Rio de Janeiro: Editora da UFMG/IUPERJ. 432 pp..

COUTINHO, João Pereira (2014), As ideias conservadoras explicadas a revolucionários e reacionários. São Paulo: Três Estrelas. 128 pp.. 
CUNHA, Diogo Arruda Carneiro da (2015), De la 'Semaine Révolutionnaire' à la 'Révolution' de 1964: itinéraire, réseaux et lieux de sociabilité de la 'génération de 1922'. Brésil(s). Sciences Humaines et Sociales. Vol. 08, pp. 215-241.

DICIONÁRIO HISTÓRICO E BIOGRÁFICO BRASILEIRO (2020), Available at $<h t t p s: / / c p d o c . f g v . b r / a c e r v o / d h b b>$. Accessed on january, 14, 2020.

DUVERGER, Maurice (1962), Ciência Política Teoria e Método. Rio de Janeiro: Zahar Editores. 438 pp..

FELDMAN, Luiz (2016), Clássico por amadurecimento: estudos sobre Raízes do Brasil. Rio de Janeiro: Topbooks. 305 pp..

FERES JÚNIOR, João and JASMIN, Marcelo Gantus (eds) (2007), História dos conceitos: diálogos transatlânticos. Rio de Janeiro: Ed. PUC-Rio: Ed. Loyola. 176 pp..

FERNANDES, Maria Fernanda Lombardi (2018), Azevedo Amaral e a Revista Novas Diretrizes: um projeto de modernização autoritária no Brasil. Revista Política Hoje. Edição Especial. Vol. 27, pp. 47-60.

FERNANDES, Maria Fernanda Lombardi (2008), A esperança e o desencanto: Silva Jardim e a República. São Paulo: Humanitas/FAPESP. 268 pp..

FERREIRA, Gabriela Nunes (1999), Centralização e descentralização no Império: o debate entre Tavares Bastos e Visconde de Uruguai. São Paulo: Editora 34. 200 pp..

FERREIRA, Gabriela Nunes and BOTELHO, André (eds) (2010), Revisão do pensamento conservador: ideias e política no Brasil. São Paulo: Hucitec/Fapesp. 384 pp..

FICO, Carlos (2003), Espionagem, polícia política, censura e propaganda: os pilares básicos da repressão. In: 0 Brasil Republicano 4.0 tempo do regime autoritário; ditadura militar e redemocratização - Quarta República. Edited by FERREIRA, Jorge and DELGADO, Lucilia de Almeida Neves. Rio de Janeiro: Civilização Brasileira. pp. 167-204.

FIC0, Carlos (1997), Reinventando o otimismo: ditadura, propaganda e imaginário social no Brasil. Rio de Janeiro: FGV. 294 pp..

FREYRE, Gilberto (2013), Casa-Grande \& Senzala. São Paulo: Global. 729 pp..

FREYRE, Gilberto (1940a), Uma cultura ameaçada: a Luso-brasileira. Lisboa: Edição Livros do Brasil. 99 pp..

FREYRE, Gilberto (1940b), o mundo que o português criou. Lisboa: Edição Livros do Brasil. 128 pp.. 
GOMES, Angela Maria de Castro (2007), Cultura política e cultura histórica no Estado Novo. In: Cultura política e leituras do passado. Edited by ABREU,Martha; GONTIJO, Rebeca, and SOIHET, Raquel. Rio de Janeiro: Civilização Brasileira. pp. 43-63.

GOMES, Angela Maria de Castro (ed) (2000), O ministro e sua correspondência: projeto político e sociabilidade intelectual. In: Capanema: o ministro e seu ministério. Rio de Janeiro: FGV. pp. 13-47.

GOMES, Angela Maria de Castro (1999a), Essa gente do rio... Modernismo e nacionalismo. Rio de Janeiro: FGV. 116 pp..

GOMES, Angela Maria de Castro (1999b), História e historiadores: a política cultural do Estado Novo. Rio de Janeiro: FGV. 220 pp..

HIRSCHMAN, Albert Otto (1991), The rhetoric of reaction: perversity, futility, jeopardy. Cambridge: Harvard University Press. 224 pp..

HOLLANDA, Cristina Buarque de (2012), Os Cadernos do Nosso Tempo e o interesse nacional. Dados. Vol. 55, pp. 607-640.

HOLLANDA, Cristina Buarque de (2009), Modos de representação política: o experimento da Primeira República Brasileira. Belo Horizonte: UFMG. 311 pp..

HUNTINGTON, Samuel P. (1957), Conservatism as an ideology. The American Political Science Review. Vol. 51, № 02, pp. 454-473.

IUMATTI, Paulo Teixeira (2018), História, dialética e diálogo com as ciências: a gênese de Formação do Brasil Contemporâneo, de Caio Prado Júnior. São Paulo: Intermeios. 540 pp..

LAMOUNIER, Bolívar (1978), Formação de um pensamento político autoritário na Primeira República: uma interpretação. In: História geral da civilização brasileira. O Brasil republicano: sociedade e instituições. Vol. 09. Edited by FAUSTO, Bóris. São Paulo: Difel. pp. 345-374.

LYNCH, Christian Edwards Cyril (2016), Cartografia do pensamento político brasileiro: conceito, história, abordagens. Dados. № 19, pp. 75-119.

LYNCH, Christian Edwards Cyril (2013), Por que pensamento e não teoria? A imaginação político-social brasileira e o fantasma da condição periférica (18801970). Dados. Vol. 56, № 04, pp. 727-767.

MAIA, Tatyana do Amaral (2010), Cardeais da cultura nacional: o Conselho Federal de Cultura e o papel cívico das políticas culturais na ditadura civil-militar (1967 - 1975). São Paulo: Itaú Cultural. 260 pp.. 
MANNHEIM, Karl (2009), La pensée conservatrice. Paris: Éditions de la revue Conférence. 158 pp..

MARTINS FILHO, João Roberto (2004), A educação dos golpistas: cultura militar, influência francesa e golpe de 1964. Paper presented at the Conference The culture of dictatorship. University of Maryland, USA.

MICELI, Ségio (1979), Intelectuais e classes dirigentes no Brasil (1920-1945). São Paulo: Difel. 210 pp..

MIGUEL, Luís Felipe (2002), Segurança e desenvolvimento: peculiaridades da ideologia de segurança nacional no Brasil. Diálogos Latinoamericanos. № 05, pp. $40-56$.

MONTELLO, Josué (1977), A cultura brasileira. Ensaio. Conferência proferida na Escola Superior de Guerra. Rio de Janeiro.

MOTA, Carlos Guilherme (2010), História e Contra-História: perfis e contrapontos. São Paulo: Globo. 432 pp..

MOTTA FILHO, Cândido (1977), Dias lidos e vividos. Memórias 2. Rio de Janeiro: Livraria José Olympio Editora. 291 pp..

MOTTA FILHO, Cândido (1968), Os elementos básicos da nacionalidade - o homem. Conferência proferida na Escola Superior de Guerra. Rio de Janeiro.

NISBET, Robert (1987), O conservadorismo. Lisboa: Estampa. 189 pp..

OAKESHOTT, Michael (1962), Rationalism in politics and others essais. London: Metheun \& Co Ldt. 582 pp..

PALLARES-BURKE, Mária Lúcia Garcia (2005), Gilberto Freire: um vitoriano dos trópicos. São Paulo: Unesp. 486 pp..

PAULA, Christiane Jalles de (2010), Gustavo Corção: militante da ordem e da autoridade. In: Revisão do pensamento conservador: ideias e política no Brasil. Edited by FERREIRA, Gabriela Nunes and BOTELHO, André. São Paulo: Hucitec/Fapesp. pp. 344-368.

REIS, José Carlos (2006), Identidades do Brasil 2. De Calmon à Bonfim. Rio de Janeiro: FGV. 240 pp.

RÉMOND, René (1982), Les droites en France. Paris: Ed. Aubier. 544 pp..

RICUPERO, Bernardo (2004), O romantismo e a ideia de nação no Brasil (1830-1870). São Paulo: Martins Fontes. 287 pp..

SADEK, Maria Tereza Aina (1978), Machiavel, Machiavéis: a tragédia octaviana. São Paulo: Símbolo. 205 pp.. 
SALLUM JÚNIOR, Brasílio (2004), Raízes do Brasil. In: Um banquete nos trópicos. Edited by MOTA, Lourenço Dantas. São Paulo: Editora Senac. pp. 235-256.

SANDRONI, Cícero and SANDRONI, Laura Constância (1998), Austregésilo de Athayde: o século de um liberal. Rio de Janeiro: Agir. 810 pp..

SANTOS, Rogério Dultra dos (2007), Francisco Campos e os Fundamentos do Constitucionalismo Antiliberal no Brasil. Dados. Vol. 50, № 02, pp. 281-323.

SANTOS, Wanderley Guilherme dos (1978), Ordem burguesa e liberalismo político. São Paulo: Duas Cidades. 172 pp..

SANTOS, Wanderley Guilherme dos (1970), Raízes da imaginação política brasileira. Dados. № 07, pp. 137-161.

SANTOS, Wanderley Guilherme dos (1967), A imaginação político-social brasileira. Dados. № 02/03, pp. 182-193.

SAPIRO, Gisèle (1999), La guerre des écrivains, 1940-1953. Paris: Fayard. 808 pp..

SARTRE, Jean-Paul (1964), Situations, tome VI: problèmes du marxisme. Paris: Gallimard. 392 pp..

SCRUTON, Roger (2017), Uma filosofia política: argumentos para o conservadorismo. São Paulo: É Realizações. 264 pp..

SCRUTON, Roger (2015), o que é conservadorismo. São Paulo: É Realizações. 328 pp..

SCHWARZ, Roberto (1978), o pai de família e outros estudos. Rio de Janeiro: Paz e Terra. 148 pp..

STEPAN, Alfred (1975), Os militares na política: a mudança de padrões na vida brasileira. Rio de Janeito: Artenova. 223 pp..

VIANNA, Luiz Werneck (2004), A revolução passiva: Iberismo e americanismo no Brasil. Rio de Janeiro: Revan. 222 pp..

VIANNA MOOG, Clodomir (1971), Do mazombo ao brasileiro. Conferência proferida na Escola Superior de Guerra. Rio de Janeiro.

WEBER, Max (2015), Economia e sociedade. Brasília: UNB. 464 pp..

WEFFORT, Francisco (2006), Formação do pensamento político brasileiro: idéias e personagens. São Paulo: Editora Ática. 360 pp.. 